Check for updates

Cite this: RSC Adv., 2020, 10, 24549

Received 13th May 2020

Accepted 9th June 2020

DOI: 10.1039/d0ra04996d

rsc.li/rsc-advances

\title{
Base-iodine-promoted metal-catalyst-free reactions of [60]fullerene with $\beta$-keto esters for the selective formation of [60]fullerene derivatives $\uparrow$
}

\author{
Han-Lin Yang, ${ }^{a}$ Li-Jun Xu, ${ }^{\text {bc }}$ Wen-Zhong Li, ${ }^{\text {a }}$ Tao Sun, ${ }^{d}$ Bao-Rong Duan, ${ }^{a}$ Si Chen (DD *a \\ and Xiang Gao (iD b
}

In this study, methanofullerenes and $2^{\prime}, 3^{\prime}$-dihydrofuran $C_{60}$ derivatives were selectively synthesized in high yields via the reactions of $C_{60}$ with $\beta$-keto esters under mild conditions by controlling the addition sequence and molar ratio of iodine and base. The structures of the products were determined by spectroscopic characterization. Moreover, a possible reaction mechanism for the selective formation of fullerene derivatives was proposed.

\section{Introduction}

Fullerenes have attracted significant attention from chemists due to their unique geometric and electronic structures. ${ }^{1-3}$ To date, the functionalization of fullerenes is of great importance for fullerene chemistry since fullerenes can be synthesized and isolated in macroscopic quantities. ${ }^{4-7}$ Various fullerene derivatives are promising for the development of diverse fullerenebased materials possessing unique properties for application in materials and biological sciences. ${ }^{8-11}$ Accordingly, methanofullerenes and $2^{\prime}, 3^{\prime}$-dihydrofuran $\mathrm{C}_{60}$ derivatives (dihydrofuran-fused $\mathrm{C}_{60}$ derivatives), as shown in Fig. 1, are classical fullerene derivatives containing a fused three- or fivemembered ring, which have been synthesized in moderate yields via the Bingel-Hirsch reaction ${ }^{12,13}$ and transition-metal catalyst-mediated $^{\mathbf{1 4 , 1 5}}$ or high-speed vibration milling (HSVM). ${ }^{16}$ However, these methods frequently suffer from drawbacks such as the requirements of high temperatures, long reaction time, the use of transition-metal catalysts, and a heterogeneous reaction. Thus, the development of more simple and efficient methods for the synthesis of methanofullerenes and $2^{\prime}, 3^{\prime}$-dihydrofuran $\mathrm{C}_{60}$ derivatives is highly desirable.

${ }^{a}$ College of Chemistry and Chemical Engineering, Yantai University, 30 Qingquan Road, Yantai, Shandong 264005, China. E-mail: sichen@ytu.edu.cn; chemchensi@ 163.com

${ }^{b}$ State Key Laboratory of Electroanalytical Chemistry, Changchun Institute of Applied Chemistry, Chinese Academy of Sciences, 5625 Renmin Street, Changchun, Jilin 130022, China

'University of Science and Technology of China, Hefei, Anhui 230026, China

${ }^{d}$ School of Materials Science and Engineering, Nanyang Technological University, Singapore 639798, Singapore

$\dagger$ Electronic supplementary information (ESI) available: Spectra of all the synthesised compounds. See DOI: 10.1039/d0ra04996d
Recently, we have selectively synthesized methanofullerenes and $2^{\prime}, 3^{\prime}$-dihydrofuran $\mathrm{C}_{60}$ derivatives as a single product in each reaction, respectively, in an iodine-base system by controlling the addition sequence and molar ratio of iodine and base, as shown in Scheme 1.

\section{Results and discussion}

Table 1 presents the screening of the reaction conditions. Ethyl acetoacetate was used for reaction screening. The experiment was designed to control the selective formation of a single product in a relatively high yield. It was divided into two types of

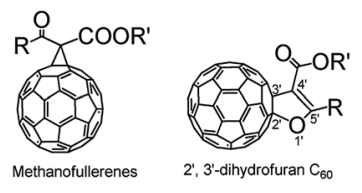

Fig. 1 Structures of methanofullerenes and $2^{\prime}, 3^{\prime}$-dihydrofuran $C_{60}$ derivatives.

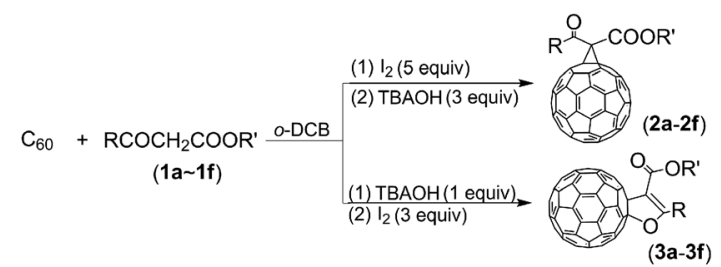

$$
\begin{array}{rr}
\text { 1a, 2a, 3a: } R=R^{\prime}=M e & \text { 1b, 2b, 3b: } R=M e, R^{\prime}=E t \\
\text { 1c, 2c, 3c: } R=M e, R^{\prime}=n-P r & \text { 1d, 2d, 3d: } R=M e, R^{\prime}=i-P r \\
\text { 1e, 2e, 3e: } R=M e, R^{\prime}=t-B u & \text { 1f, 2f, 3f: } R=E t, R^{\prime}=M e
\end{array}
$$

Scheme 1 Synthesis of the compounds $2 a-2 f$ and $3 a-3 f$. 
Table 1 Screening of the reaction conditions using ethyl acetoacetate ${ }^{a}$

\begin{tabular}{|c|c|c|c|c|c|c|c|}
\hline \multirow[b]{2}{*}{ Entry } & \multirow[b]{2}{*}{$\mathrm{OH}^{-}$(equiv.) } & \multirow[b]{2}{*}{$\mathrm{I}_{2}$ (equiv.) } & \multirow[b]{2}{*}{ Temp $\left({ }^{\circ} \mathrm{C}\right)$} & \multirow[b]{2}{*}{$\operatorname{Time}^{b}$ (min) } & \multirow[b]{2}{*}{ Time $^{c}(\mathrm{~min})$} & \multicolumn{2}{|c|}{ Product (\% yield $)^{d}$} \\
\hline & & & & & & $2 \mathbf{b}$ & $3 \mathbf{b}$ \\
\hline 2 & 3 & 5 & 0 & 60 & 60 & $9(22)$ & $28(69)$ \\
\hline 3 & 3 & 5 & $\mathrm{rt}$ & 30 & 30 & $32(36)$ & $18(20)$ \\
\hline 4 & 3 & 5 & $\mathrm{rt}$ & 30 & 60 & $29(36)$ & $18(22)$ \\
\hline 7 & 3 & 5 & 50 & 30 & 60 & $26(34)$ & $19(25)$ \\
\hline 8 & 1 & 3 & 0 & 30 & 30 & Trace & $28(70)$ \\
\hline 9 & 1 & 3 & $\mathrm{rt}$ & 30 & 30 & 7 (19) & $27(73)$ \\
\hline 10 & 1.2 & 3 & $\mathrm{rt}$ & 30 & 30 & $9(23)$ & $27(69)$ \\
\hline 11 & 5 & 8 & $\mathrm{rt}$ & 30 & 30 & - & - \\
\hline $12^{e}$ & 3 & 5 & $\mathrm{rt}$ & - & 60 & $52(65)$ & - \\
\hline
\end{tabular}

${ }^{a}$ Reaction conditions: (1) for the entries from 1 to $11, \mathrm{C}_{60}(36 \mathrm{mg}, 50 \mu \mathrm{mol})$ and ethyl acetoacetate $(500 \mu \mathrm{L}, 79$ equiv.) were put in $o$-DCB (odichlorobenzene) $(15 \mathrm{~mL})$. The mixture was stirred for $15 \mathrm{~min}$ under argon or nitrogen at a preset temperature. Then, $\mathrm{OH}^{-}\left(\mathrm{TBAOH}^{-}\right.$tetra- $n-$ butylammonium hydroxide, $1.0 \mathrm{M}$ in $\mathrm{CH}_{3} \mathrm{OH}$ ) was added to the solution, and the reaction was allowed to proceed for a definite time ${ }^{b}$. The reaction was then quenched with $\mathrm{I}_{2}$ for a definite time ${ }^{c}$. (2) For the entries from 12 to $15, \mathrm{C}_{60}(36 \mathrm{mg}, 50 \mu \mathrm{mol})$, ethyl acetoacetate $(500 \mu \mathrm{L}, 79$ equiv.), and $\mathrm{I}_{2}$ were put into $o$-DCB $(15 \mathrm{~mL})$. The mixture was stirred for 15 min under argon or nitrogen at a preset temperature. Then, OH ${ }^{-}$ (TBAOH, $1.0 \mathrm{M}$ in $\mathrm{CH}_{3} \mathrm{OH}$ ) was added to the solution, and the reaction was allowed to proceed for a definite time ${ }^{\mathrm{c} .}{ }^{b}$ Reaction time after base addition and before the addition of iodine. ${ }^{c}$ Reaction time after iodine addition. ${ }^{d}$ Yield in parentheses based on the consumed $\mathrm{C}_{60} \cdot{ }^{e}$ Addition sequence is different from the entries 1 to 11 , that is, iodine is added first followed by the addition of the base.

reactions according to the addition sequence of base and iodine as follows: (1) reaction involving the addition of base first and iodine later (entries from 1 to 11 ) and (2) reaction involving the addition of iodine first and base later (entries from 12 to 15 ). Both the compounds $\mathbf{2 b}$ and $\mathbf{3 b}$ were obtained when 3 equiv. of $\mathrm{OH}^{-}$with respect to $\mathrm{C}_{60}$ was first added to the reaction mixture followed by the addition of 5 equiv. of iodine with respect to $\mathrm{C}_{60}$ (entries from 1 to 7 ). Interestingly, only $\mathbf{3} \mathbf{b}$ was obtained when the reaction was conducted at $0{ }^{\circ} \mathrm{C}$ by first adding 1 equiv. of $\mathrm{OH}^{-}$followed by the addition of 3 equiv. of iodine (entry 8).
Upon further increasing the amount of base to 5 equiv. and that of iodine to 8 equiv., a crude product was obtained, which was quite complex and difficult to separate, as indicated by the HPLC measurement performed using a Buckyprep column (entry 11). However, a reduction in the amount of iodine would result in bis-2 $2^{\prime}, 3^{\prime}$-dihydrofuran $\mathrm{C}_{60}$ derivatives. ${ }^{17}$ In contrast, only $\mathbf{2 b}$ was obtained when the reaction was carried out at room temperature by first adding 5 equiv. of iodine followed by the addition of 3 or 4 equiv. of $\mathrm{OH}^{-}$(entries 12 and 13). To achieve $2 \mathbf{b}$ in a higher yield, it was better to use 3 equiv. of $\mathrm{OH}^{-}(52 \%$

Table 2 Conditions for the preparation of the compounds $2 a-2 f$ and $3 a-3 f$

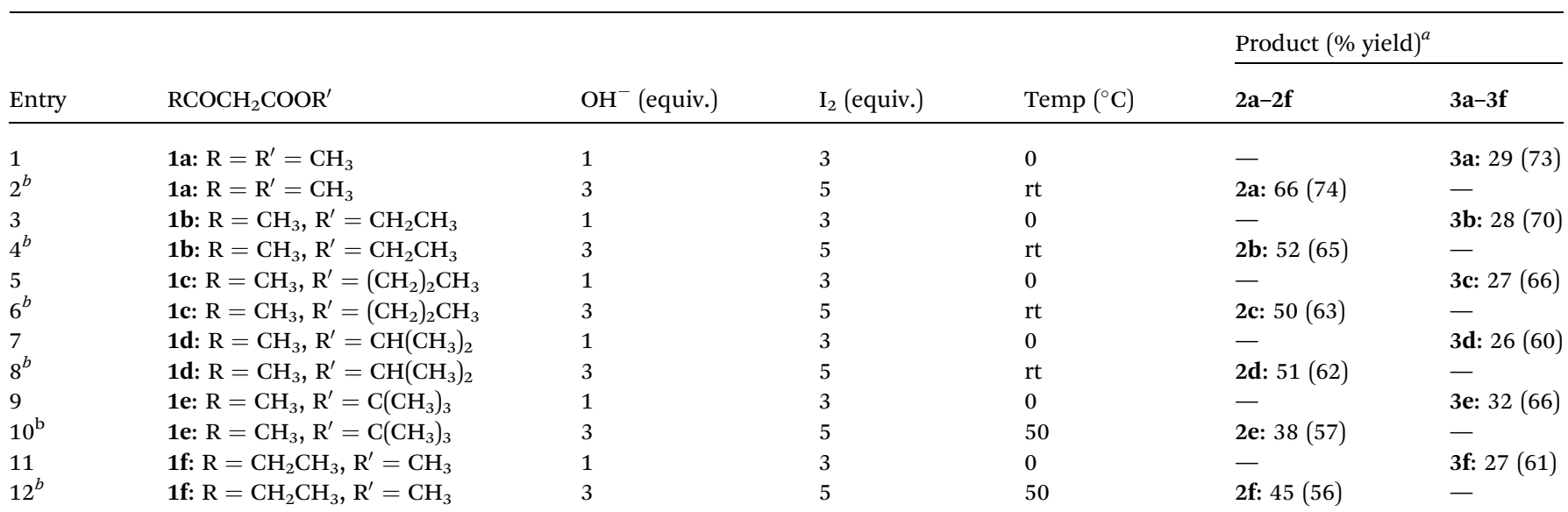

${ }^{a}$ Yield in parentheses based on the consumed $\mathrm{C}_{60} \cdot{ }^{b}$ Addition sequence is different from that for the other entries (the addition sequence of the entries 1, 3, 5, 7, 9, and 11 involves the addition of base first and iodine later), that is, the addition of iodine first and base later. 
isolated yield, $65 \%$ yield based on the consumed $\mathrm{C}_{60}$ ) (entry 12 ). Similarly, upon further increasing the amount of base to 5 equiv. and that of iodine to 5 or 8 equiv., a crude product was obtained, which was quite complex and difficult to purify, as shown by the HPLC measurement conducted using the Buckyprep column (entries 14 and 15).

The reactions were further examined using other $\beta$-keto ester substrates (1a, 1c-1f) listed in Table 2. It was found that the methods were effective for the selective preparation of methanofullerenes (2a-2f) and $2^{\prime}, 3^{\prime}$-dihydrofuran $\mathrm{C}_{60}$ derivatives (3a3f) in relatively high yields. Methanofullerenes (2a-2f) could be obtained with the isolated yield of $38-66 \%$ (56-74\% based on the consumed $\mathrm{C}_{60}$ ) by adding iodine first and base later. However, the formation of $2^{\prime}, 3^{\prime}$-dihydrofuran $\mathrm{C}_{60}$ derivatives (3a-3f) with the isolated yield of $26-32 \%(60-73 \%$ based on the consumed $\mathrm{C}_{60}$ ) could be controlled by adding base first and iodine later. Generally, $0{ }^{\circ} \mathrm{C}$ was good for the synthesis of $2^{\prime}, 3^{\prime}$ dihydrofuran $\mathrm{C}_{60}$ derivatives, and room temperature was good for the synthesis of methanofullerenes, except for $\mathbf{2 e}$ and $\mathbf{2 f}$. Consequently, we found that $50{ }^{\circ} \mathrm{C}$ was better for the preparation of $2 \mathbf{e}$ and $2 \mathbf{f}$.

The structures of the compounds $\mathbf{2 a - 2 f}$ and $\mathbf{3 a - 3 f}$ were characterized by MALDI-TOF MS and ${ }^{1} \mathrm{H}$ NMR, ${ }^{13} \mathrm{C}$ NMR, and UV-vis spectroscopies. The MALDI-TOF MS spectrum of each compound exhibits a molecular ion peak that well matches with the theoretical value (see figures in ESI $\dagger$ ). The resonances of the alkyl protons are shown in the ${ }^{1} \mathrm{H}$ NMR spectra. The UV-vis spectra of all the compounds exhibit peaks at around $428 \mathrm{~nm}$, which is attributed to the diagnostic absorption of the $1: 1$ cycloadduct of $\mathrm{C}_{60}$ at the 6,6-junction. ${ }^{16}$ For example, the MALDI-TOF MS spectrum of the compound $2 f$ (Fig. S42 $\dagger$ ) shows a molecular ion peak at $m / z$ 848.0437. The ${ }^{13} \mathrm{C}$ NMR spectrum of $2 f$ (Fig. S44 $\dagger$ ) exhibits 22 peaks for the $\mathrm{sp}^{2}$ carbon atoms of $\mathrm{C}_{60}$, in agreement with the $C_{\mathrm{s}}$ symmetry of the molecule, two peaks at $195.93 \mathrm{ppm}$ and $164.22 \mathrm{ppm}$ due to the two carbonyl carbons in $\beta$-keto ester, respectively, and one peak at $72.31 \mathrm{ppm}$ due to the two $\mathrm{sp}^{3}$ carbons of the $\mathrm{C}_{60}$ cage. The MALDI-TOF MS spectrum of the compound $3 f$ (Fig. S46†) similarly shows a molecular ion peak at $\mathrm{m} / \mathrm{z} 848.0425$. However, the ${ }^{13} \mathrm{C}$ NMR spectrum of $3 \mathbf{f}$ (Fig. S48†) displays 30 peaks for the $\mathrm{sp}^{2}$ carbon atoms of $\mathrm{C}_{60}$, consistent with the $C_{\mathrm{s}}$ symmetry of the molecule, one peak at $173.88 \mathrm{pm}$ due to the $5^{\prime}$-carbon atom of the heterocycle, one signal at $164.52 \mathrm{ppm}$ due to the carbonyl carbon atom, one peak

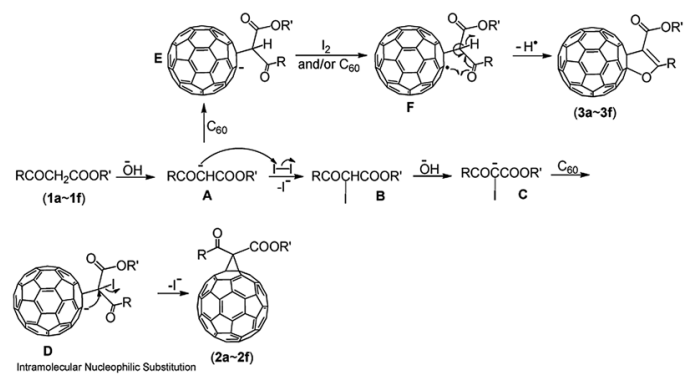

Scheme 2 Proposed mechanism for the formation of the compounds $2 a-2 f$ and $3 a-3 f$. at $104.26 \mathrm{ppm}$ due to the $4^{\prime}$-carbon atom of the heterocycle, and two peaks at $102.87 \mathrm{ppm}$ and $72.31 \mathrm{ppm}$ assigned to the two $\mathrm{sp}^{3}$ carbons of the $\mathrm{C}_{60}$ cage.

The proposed reaction mechanism for the formation of the compounds $\mathbf{2 a - 2 f}$ and 3a-3f is shown in Scheme 2. The reaction is initiated by the abstraction of an $\alpha$-proton from $\beta$-keto esters (1a-1f) to generate the enolate anion $\mathbf{A}$, which can either react with $I_{2}$ to afford the intermediate $\mathbf{B}$ when $I_{2}$ is present in the mixture at the beginning of the reaction, or attack $\mathrm{C}_{60}$ to form the intermediate $\mathbf{E}\left(\mathrm{RC}_{60}{ }^{-}\right)$when $\mathrm{I}_{2}$ is absent. The subsequent abstraction of an $\alpha^{\prime}$-proton from the $\beta$-keto ester moiety in $\mathbf{B}$ would take place to generate the intermediate $\mathbf{C}$ when extra $\mathrm{OH}^{-}$is present. Then, the intermediate $\mathbf{C}$ would attack $\mathrm{C}_{60}$ and afford the intermediate $\mathbf{D}$, followed by intramolecular nucleophilic substitution to provide methanofullerenes (2a-2f). In contrast, the intermediate $\mathbf{E}$ is completely oxidized by $\mathrm{I}_{2}$ or partially oxidized by another molecule of neutral $\mathrm{C}_{60}$ to obtain the radical $\mathbf{F}$ in the presence of less $\mathrm{OH}^{-}$. Intramolecular cyclization of the radical $\mathbf{F}$ with the release of a hydrogen radical affords the $2^{\prime}, 3^{\prime}$-dihydrofuran $\mathrm{C}_{60}$ derivatives (3a-3f).

\section{Conclusions}

The chemistry presented herein provides rapid access to methanofullerenes and $2^{\prime}, 3^{\prime}$-dihydrofuran $\mathrm{C}_{60}$ derivatives in high yields. The addition sequence of iodine and base is crucial for the control over the formation of these two types of products. Methanofullerenes can be selectively afforded by adding iodine first and base later. However, the $2^{\prime}, 3^{\prime}$-dihydrofuran $\mathrm{C}_{60}$ derivatives were obtained by adding base first and iodine later. These simple and benign methods are highly selective, have short reaction times, and do not require transition metal catalysts.

\section{Experimental}

\section{General methods}

All reactions were carried out under an argon or nitrogen atmosphere. All reagents were commercially obtained and used without further purification.

\section{Preparation and spectral characterization of $2 \mathrm{a}$}

Typically, $36 \mathrm{mg}$ of $\mathrm{C}_{60}(0.05 \mathrm{mmol}), 89$ equiv. of $1 \mathrm{a}(4.47 \mathrm{mmol}$, $500 \mu \mathrm{L})$, and 5 equiv. of $\mathrm{I}_{2}(0.25 \mathrm{mmol}, 63 \mathrm{mg})$ were added to $o$ DCB $(15 \mathrm{~mL})$ followed by stirring under an argon or nitrogen atmosphere for $15 \mathrm{~min}$ at room temperature. Then, 3.0 equiv. of TBAOH (1.0 $\mathrm{M}$ in methanol, $150 \mu \mathrm{L}, 0.15 \mathrm{mmol})$ was added to the abovementioned solution, and the reaction was allowed to proceed for $60 \mathrm{~min}$. The solvent of the reaction mixture was removed using a rotary evaporator under vacuum, and the residue was separated using a silica gel column with $\mathrm{CS}_{2} /$ toluene $(4: 1 \mathrm{v} / \mathrm{v})$ as the eluent to obtain methanofullerene $2 \mathrm{a}$ (27.5 $\mathrm{mg}, 74 \%$ based on the consumed $\mathrm{C}_{60}$ ) as an amorphous brown solid along with the recovered $\mathrm{C}_{60}$ (4.0 mg, 11\%). MALDITOF MS $m / z$ calcd for $\mathrm{C}_{65} \mathrm{H}_{6} \mathrm{O}_{3}{ }^{+}[\mathrm{M}]^{+}$834.0311, found 834.0305. ${ }^{1} \mathrm{H}$ NMR (600 MHz, DMSO) $\delta 3.84(\mathrm{~s}, 3 \mathrm{H}), 2.56(\mathrm{~s}, 3 \mathrm{H}) .{ }^{13} \mathrm{C} \mathrm{NMR}$ $(151 \mathrm{MHz}, \mathrm{DMSO}) \delta 190.60\left(1 \mathrm{C}, \mathrm{COCH}_{3}\right), 163.23$ (1C, 
$\mathrm{CO}_{2} \mathrm{CH}_{2} \mathrm{CH}_{3}$ ), 145.24 (2C), 144.99 (6C), 144.92 (5C), 144.83 (2C), 144.71 (2C), 144.55 (2C), 144.52 (1C), 144.47 (4C), 144.37 (4C), 143.62 (2C), 143.60 (2C), 142.92 (1C), 142.87 (1C), 142.80 (8C), 142.02 (4C), 141.62 (2C), 141.59 (2C), 140.83 (2C), 140.79 (2C), 139.10 (2C), 137.98 (2C), 72.25 (2C, sp ${ }^{3} C$ of $\mathrm{C}_{60}$ ), 59.06 (1C, $\left.\mathrm{CCOCH}_{3}\right), 53.21\left(1 \mathrm{C}, \mathrm{OCH}_{3}\right), 27.86\left(1 \mathrm{C}, \mathrm{COCH}_{3}\right)$. UV-vis (in toluene) $\lambda_{\max }: 328,428 \mathrm{~nm}$.

\section{Preparation and spectral characterization of $3 \mathbf{a}$}

Typically, $36 \mathrm{mg}$ of $\mathrm{C}_{60}(0.05 \mathrm{mmol})$ and 89 equiv. of 1a $(4.47 \mathrm{mmol}, 500 \mu \mathrm{L})$ were added to $o$-DCB $(15 \mathrm{~mL})$ followed by stirring under an argon or nitrogen atmosphere for $15 \mathrm{~min}$ at $0{ }^{\circ} \mathrm{C}$. Then, 1.0 equiv. of TBAOH $(1.0 \mathrm{M}$ in methanol, $50 \mu \mathrm{L}, 0.05$ mmol) was added to the abovementioned solution, and the reaction was allowed to proceed for $30 \mathrm{~min}$. The reaction mixture was then quenched with 3 equiv. of $I_{2}(0.15 \mathrm{mmol}, 38 \mathrm{mg})$ for $30 \mathrm{~min}$. The solvent of the reaction mixture was removed using a rotary evaporator under vacuum, and the residue was separated using a silica gel column with $\mathrm{CS}_{2} /$ toluene $(4: 1 \mathrm{v} / \mathrm{v})$ as the eluent to afford $2^{\prime}, 3^{\prime}$-dihydrofuran fullerene $3 \mathbf{a}(12.1 \mathrm{mg}, 73 \%$ based on the consumed $\mathrm{C}_{60}$ ) as an amorphous brown solid along with the recovered $\mathrm{C}_{60}(21.6 \mathrm{mg}, 60 \%)$. MALDI-TOF $\mathrm{MS} \mathrm{m} / \mathrm{z}$ calcd for $\mathrm{C}_{65} \mathrm{H}_{6} \mathrm{O}_{3}{ }^{+}[\mathrm{M}]^{+}$834.0311, found 834.0285. ${ }^{1} \mathrm{H}$ NMR $(600 \mathrm{MHz}$, DMSO) $\delta 3.58(\mathrm{~s}, 3 \mathrm{H}), 2.62(\mathrm{~s}, 3 \mathrm{H}) .{ }^{13} \mathrm{C}$ NMR (151 MHz, DMSO) $\delta 168.71\left(1 \mathrm{C}, \mathrm{OCCH}_{3}\right), 163.39(1 \mathrm{C}, C=\mathrm{O}), 148.39(2 \mathrm{C}), 147.82(1 \mathrm{C})$, 147.16 (2C), 147.11 (1C), 146.24 (2C), 146.03 (2C), 145.97 (2C), 145.83 (2C), 145.76 (2C), 145.45 (2C), 145.20 (2C), 144.98 (2C), 144.83 (2C), 144.59 (2C), 144.35 (2C), 144.24 (2C), 144.03 (2C), 142.63 (2C), 142.60 (2C), 142.51 (2C), 142.38 (2C), 142.28 (2C), 142.15 (2C), 142.10 (2C), 141.42 (2C), 141.29 (2C), 139.71 (2C), 139.32 (2C), 137.25 (2C), 135.06 (2C), 105.03 (1C, $C \mathrm{C}=\mathrm{O}), 50.84$ (1C, $\left.\mathrm{OCH}_{3}\right), 15.40\left(1 \mathrm{C}, \mathrm{CH}_{3}\right),\left(\mathrm{sp}^{3}-\mathrm{C}\right.$ of $\mathrm{C}_{60}$ not found). UV-vis (in toluene) $\lambda_{\text {max }}: 319,428 \mathrm{~nm}$.

\section{Preparation and spectral characterization of $2 \mathrm{~b}$}

The procedure was similar to that used for the preparation of $2 \mathbf{a}$, except that $\mathbf{1 b}$ (79 equiv., $3.95 \mathrm{mmol}, 500 \mu \mathrm{L}$ ) was used instead of 1a. The reaction afforded $2 \mathbf{b}(22.0 \mathrm{mg}, 65 \%$ based on the consumed $\mathrm{C}_{60}$ ) as an amorphous brown solid along with the recovered $\mathrm{C}_{60}(7.2 \mathrm{mg}, 20 \%)$. MALDI-TOF $\mathrm{MS} \mathrm{m} / \mathrm{z}$ calcd for $\mathrm{C}_{66} \mathrm{H}_{8} \mathrm{O}_{3}{ }^{+}[\mathrm{M}]^{+}$848.0468, found 848.0438. ${ }^{1} \mathrm{H}$ NMR $(600 \mathrm{MHz}$, DMSO) $\delta 4.31(\mathrm{q}, J=7.2 \mathrm{~Hz}, 2 \mathrm{H}), 2.61(\mathrm{~s}, 3 \mathrm{H}), 1.30(\mathrm{t}, J=7.2 \mathrm{~Hz}$, $3 \mathrm{H}) .{ }^{13} \mathrm{C}$ NMR (151 MHz, DMSO) $\delta 190.62\left(1 \mathrm{C}, \mathrm{COCH}_{3}\right), 162.71$ (1C, $\mathrm{CO}_{2} \mathrm{CH}_{2} \mathrm{CH}_{3}$ ), 145.35 (2C), 145.03 (2C), 145.00 (3C), 144.92 (5C), 144.86 (2C), 144.78 (2C), 144.54 (4C), 144.50 (1C), 144.47 (3C), 144.35 (4C), 143.63 (2C), 143.61 (2C), 142.93 (1C), 142.88 (1C), 142.81 (6C), 142.78 (2C), 142.03 (4C), 141.60 (4C), 140.83 (2C), 140.78 (2C), 139.13 (2C), 137.95 (2C), 72.26 (2C, $\mathrm{sp}^{3}-\mathrm{C}$ of $\mathrm{C}_{60}$ ), $63.06\left(1 \mathrm{C}, \mathrm{OCH}_{2} \mathrm{CH}_{3}\right), 59.23\left(1 \mathrm{C}, \mathrm{CCOCH}_{3}\right), 27.83\left(1 \mathrm{C}, \mathrm{COCH}_{3}\right)$, $14.46\left(1 \mathrm{C}, \mathrm{CH}_{2} \mathrm{CH}_{3}\right)$. UV-vis (in toluene) $\lambda_{\text {max }}: 326,429 \mathrm{~nm}$.

\section{Preparation and spectral characterization of $3 b$}

The procedure was similar to that used for the preparation of 3a, except that $\mathbf{1 b}$ (79 equiv., $3.95 \mathrm{mmol}, 500 \mu \mathrm{L}$ ) was used instead of 1a. The reaction afforded $3 \mathbf{b}(11.8 \mathrm{mg}, 70 \%$ based on the consumed $\mathrm{C}_{60}$ ) as an amorphous brown solid along with the recovered $\mathrm{C}_{60}(21.6 \mathrm{mg}, 60 \%)$. MALDI-TOF $\mathrm{MS} \mathrm{m} / \mathrm{z}$ calcd for $\mathrm{C}_{66} \mathrm{H}_{8} \mathrm{O}_{3}{ }^{+}[\mathrm{M}]^{+}$848.0468, found 848.0495. ${ }^{1} \mathrm{H}$ NMR $(600 \mathrm{MHz}$, DMSO) $\delta 4.05(\mathrm{q}, J=7.2 \mathrm{~Hz}, 2 \mathrm{H}), 2.61(\mathrm{~s}, 3 \mathrm{H}), 1.07$ (t, $J=7.2 \mathrm{~Hz}$, 3H). ${ }^{13} \mathrm{C}$ NMR (151 MHz, DMSO) $\delta 168.57$ (1C, $\left.\mathrm{OCCH}_{3}\right), 162.99$ (1C, $C=\mathrm{O}), 148.43$ (2C), 147.82 (1C), 147.32 (2C), 147.11 (1C), 146.25 (2C), 146.02 (2C), 145.97 (2C), 145.82 (2C), 145.76 (2C), 145.47 (2C), 145.20 (2C), 144.98 (2C), 144.82 (2C), 144.62 (2C), 144.36 (2C), 144.32 (2C), 144.05 (2C), 142.64 (2C), 142.60 (2C), 142.52 (2C), 142.40 (2C), 142.29 (2C), 142.15 (2C), 142.11 (2C), 141.39 (2C), 141.30 (2C), 139.72 (2C), 139.15 (2C), 137.24 (2C), $135.06(2 \mathrm{C}), 104.80(1 \mathrm{C}, C \mathrm{C}=\mathrm{O}), 102.50\left(1 \mathrm{C}, \mathrm{sp}^{3}-\mathrm{C}\right.$ of $\left.\mathrm{C}_{60}, \mathrm{C}_{60}-\mathrm{O}\right)$, 72.07 (1C, $\mathrm{sp}^{3}-\mathrm{C}$ of $\mathrm{C}_{60}, \mathrm{C}_{60}-\mathrm{C}$ ), $60.28\left(1 \mathrm{C}, \mathrm{OCH}_{2} \mathrm{CH}_{3}\right), 15.36$ (1C, $\left.\mathrm{CH}_{3}\right), 14.52\left(1 \mathrm{C}, \mathrm{CH}_{2} \mathrm{CH}_{3}\right)$. UV-vis (in toluene) $\lambda_{\max }: 320,429 \mathrm{~nm}$.

\section{Preparation and spectral characterization of $2 \mathrm{c}$}

The procedure was similar to that used for the preparation of 2a, except that 1c (70 equiv., $3.50 \mathrm{mmol}, 500 \mu \mathrm{L}$ ) was used instead of 1a. The reaction afforded $2 \mathrm{c}(21.6 \mathrm{mg}, 63 \%$ based on the consumed $\mathrm{C}_{60}$ ) as an amorphous brown solid along with the recovered $\mathrm{C}_{60}(7.6 \mathrm{mg}, 21 \%)$. MALDI-TOF MS $\mathrm{m} / \mathrm{z}$ calcd for $\mathrm{C}_{67} \mathrm{H}_{10} \mathrm{O}_{3}{ }^{+}[\mathrm{M}]^{+}$862.0624, found 862.0601. ${ }^{1} \mathrm{H}$ NMR $(500 \mathrm{MHz}$, $\left.\mathrm{CDCl}_{3}\right) \delta 4.48(\mathrm{t}, J=7.0 \mathrm{~Hz}, 2 \mathrm{H}), 2.87(\mathrm{~s}, 3 \mathrm{H}), 1.92(\mathrm{~m}, 2 \mathrm{H}), 1.13$ $(\mathrm{t}, J=7.5 \mathrm{~Hz}, 3 \mathrm{H}) .{ }^{13} \mathrm{C} \mathrm{NMR}\left(151 \mathrm{MHz}, \mathrm{CDCl}_{3}\right) \delta 191.83(1 \mathrm{C}$, $\mathrm{COCH}_{3}$ ), $163.10\left(1 \mathrm{C}, \mathrm{CO}_{2} \mathrm{CH}_{2} \mathrm{CH}_{2} \mathrm{CH}_{3}\right), 145.20(2 \mathrm{C}), 144.92(3 \mathrm{C})$, 144.91 (2C), 144.85 (5C), 144.76 (2C), 144.54 (2C), 144.48 (3C), 144.41 (3C), 144.38 (4C), 144.28 (2C), 144.27 (2C), 143.54 (1C), 143.51 (2C), 142.84 (1C), 142.80 (1C), 142.72 (6C), 142.67 (2C), 141.93 (4C), 141.53 (2C), 141.50 (2C), 140.75 (2C), 140.69 (1C), 139.12 (2C), 137.73 (2C), 72.11 (2C, $\mathrm{sp}^{3}-C$ of $\mathrm{C}_{60}$ ), 68.59 (1C, $\left.\mathrm{CO}_{2} \mathrm{CH}_{2} \mathrm{CH}_{2} \mathrm{CH}_{3}\right), 59.07\left(1 \mathrm{C}, \mathrm{CCOCH}_{3}\right), 28.03\left(1 \mathrm{C}, \mathrm{COCH}_{3}\right.$ ), 22.24 (1C, $\mathrm{CH}_{2} \mathrm{CH}_{2} \mathrm{CH}_{3}$ ), 10.54 (1C, $\mathrm{CH}_{2} \mathrm{CH}_{2} \mathrm{CH}_{3}$ ). UV-vis (in toluene) $\lambda_{\max }: 329,429 \mathrm{~nm}$.

\section{Preparation and spectral characterization of $3 \mathrm{c}$}

The procedure was similar to that used for the preparation of 3a, except that 1c (70 equiv., $3.50 \mathrm{mmol}, 500 \mu \mathrm{L}$ ) was used instead of 1a. The reaction afforded $3 \mathrm{c}(11.6 \mathrm{mg}, 66 \%$ based on the consumed $\mathrm{C}_{60}$ ) as an amorphous brown solid along with the recovered $\mathrm{C}_{60}(21.2 \mathrm{mg}, 59 \%)$. MALDI-TOF $\mathrm{MS} \mathrm{m} / \mathrm{z}$ calcd for $\mathrm{C}_{67} \mathrm{H}_{10} \mathrm{O}_{3}{ }^{+}[\mathrm{M}]^{+}$862.0624, found 862.0609. ${ }^{1} \mathrm{H}$ NMR $(600 \mathrm{MHz}$, $\left.\mathrm{CDCl}_{3}\right) \delta 4.25(\mathrm{t}, J=7.2 \mathrm{~Hz}, 2 \mathrm{H}), 2.89(\mathrm{~s}, 3 \mathrm{H}), 1.73(\mathrm{~m}, 2 \mathrm{H}), 1.00$ $(\mathrm{t}, J=7.2 \mathrm{~Hz}, 3 \mathrm{H}) .{ }^{13} \mathrm{C} \mathrm{NMR}\left(151 \mathrm{MHz}, \mathrm{CDCl}_{3}\right) \delta 169.01(1 \mathrm{C}$, $\mathrm{OCCH}_{3}$ ), $164.00(1 \mathrm{C}, C=\mathrm{O}), 148.44$ (2C), 147.93 (1C), 147.23 (3C), 146.35 (2C), 146.13 (2C), 146.07 (2C), 145.93 (2C), 145.87 (2C), 145.56 (2C), 145.29 (2C), 145.09 (2C), 144.93 (2C), 144.67 (2C), 144.44 (2C), 144.33 (2C), 144.14 (2C), 142.72 (2C), 142.69 (2C), 142.61 (2C), 142.47 (2C), 142.36 (2C), 142.24 (2C), 142.20 (2C), 141.48 (2C), 141.37 (2C), 139.81 (2C), 139.31 (2C), 137.38 (2C), 135.20 (2C), $105.01(1 \mathrm{C}, C \mathrm{C}=\mathrm{O}), 66.12\left(1 \mathrm{C}, \mathrm{CO}_{2} \mathrm{CH}_{2} \mathrm{CH}_{2}\right.$ $\mathrm{CH}_{3}$ ), 22.42 (1C, $\mathrm{CH}_{2} \mathrm{CH}_{2} \mathrm{CH}_{3}$ ), 15.52 (1C, $\left.\mathrm{CH}_{3}\right), 10.93$ (1C, $\mathrm{CH}_{2} \mathrm{CH}_{2} \mathrm{CH}_{3}$ ), ( $\mathrm{sp}^{3}$-C of $\mathrm{C}_{60}$ not found). UV-vis (in toluene) $\lambda_{\max }$ : $320,429 \mathrm{~nm}$.

\section{Preparation and spectral characterization of $2 \mathrm{~d}$}

The procedure was similar to that used for the preparation of 2a, except that 1d (69 equiv., $3.44 \mathrm{mmol}, 500 \mu \mathrm{L}$ ) was used 
instead of 1a. The reaction afforded $2 \mathrm{~d}(22.0 \mathrm{mg}, 62 \%$ based on the consumed $\mathrm{C}_{60}$ ) as an amorphous brown solid along with the recovered $\mathrm{C}_{60}(6.5 \mathrm{mg}, 18 \%)$. MALDI-TOF $\mathrm{MS} \mathrm{m} / \mathrm{z}$ calcd for $\mathrm{C}_{67} \mathrm{H}_{10} \mathrm{O}_{3}{ }^{+}[\mathrm{M}]^{+}$862.0624, found 862.0645. ${ }^{1} \mathrm{H}$ NMR $(600 \mathrm{MHz}$, $\left.\mathrm{CDCl}_{3}\right) \delta 5.42(\mathrm{~m}, 1 \mathrm{H}), 2.85(\mathrm{~s}, 3 \mathrm{H}), 1.52(\mathrm{~d}, J=6.6 \mathrm{~Hz}, 6 \mathrm{H}) .{ }^{13} \mathrm{C}$ NMR (151 MHz, $\left.\mathrm{CDCl}_{3}\right) \delta 192.60\left(1 \mathrm{C}, \mathrm{COCH}_{3}\right.$, overlapped with the peak of $\left.\mathrm{CS}_{2}\right), 163.01\left(1 \mathrm{C}, \mathrm{CO}_{2} \mathrm{CH}\left(\mathrm{CH}_{3}\right)_{2}\right), 145.59$ (2C), 145.33 (2C), 145.29 (2C), 145.28 (2C), 145.22 (4C), 145.16 (2C), 144.96 (2C), 144.84 (2C), 144.79 (2C), 144.75 (4C), 144.64 (4C), 143.91 (2C), 143.89 (2C), 143.22 (1C), 143.18 (1C), 143.09 (6C), 143.04 (2C), 142.30 (4C), 141.91 (2C), 141.86 (2C), 141.11 (2C), 141.05 (2C), 139.44 (2C), 138.14 (2C), 72.52 (2C, $\mathrm{sp}^{3}-C$ of $\mathrm{C}_{60}$ ), 71.79 (1C, $\left.\mathrm{OCH}\left(\mathrm{CH}_{3}\right)_{2}\right), 59.54\left(1 \mathrm{C}, \mathrm{CCOCH}_{3}\right), 28.43\left(1 \mathrm{C}, \mathrm{COCH}_{3}\right), 21.93(2 \mathrm{C}$, $\left.\mathrm{CH}\left(\mathrm{CH}_{3}\right)_{2}\right)$. UV-vis (in toluene) $\lambda_{\text {max }}: 330,429 \mathrm{~nm}$.

\section{Preparation and spectral characterization of $3 d$}

The procedure was similar to that used for the preparation of 3a, except that 1d (69 equiv., $3.44 \mathrm{mmol}, 500 \mu \mathrm{L}$ ) was used instead of 1a. The reaction afforded $3 d$ (11.2 $\mathrm{mg}$, $60 \%$ based on the consumed $\mathrm{C}_{60}$ ) as an amorphous brown solid along with the recovered $\mathrm{C}_{60}(20.5 \mathrm{mg}, 57 \%)$. MALDI-TOF $\mathrm{MS} \mathrm{m} / \mathrm{z}$ calcd for $\mathrm{C}_{67} \mathrm{H}_{10} \mathrm{O}_{3}{ }^{+}[\mathrm{M}]^{+}$862.0624, found 862.0660. ${ }^{1} \mathrm{H}$ NMR $(600 \mathrm{MHz}$, $\left.\mathrm{CDCl}_{3}\right) \delta 5.24(\mathrm{~m}, 1 \mathrm{H}), 2.88(\mathrm{~s}, 3 \mathrm{H}), 1.33(\mathrm{~d}, J=6.0 \mathrm{~Hz}, 6 \mathrm{H}) .{ }^{13} \mathrm{C}$ NMR (151 MHz, $\left.\mathrm{CDCl}_{3}\right) \delta 169.04\left(1 \mathrm{C}, \mathrm{OCCH}_{3}\right), 163.81$ (1C, $C=$ O), 148.68 (2C), 148.13 (1C), 147.55 (2C), 147.41 (1C), 146.55 (2C), 146.32 (2C), 146.26 (2C), 146.12 (2C), 146.06 (2C), 145.77 (2C), 145.49 (2C), 145.29 (2C), 145.12 (2C), 144.88 (2C), 144.65 (2C), 144.58 (2C), 144.34 (2C), 142.92 (2C), 142.88 (2C), 142.80 (2C), 142.67 (2C), 142.56 (2C), 142.44 (2C), 142.40 (2C), 141.68 (2C), 141.57 (2C), 140.00 (2C), 139.42 (2C), 137.58 (2C), 135.38 (2C), $105.24(1 \mathrm{C}, C \mathrm{C}=\mathrm{O}), 102.80\left(1 \mathrm{C}, \mathrm{sp}^{3}-\mathrm{C}\right.$ of $\left.\mathrm{C}_{60}, \mathrm{C}_{60}-\mathrm{O}\right), 72.34$ $\left(1 \mathrm{C}, \mathrm{sp}^{3}-\mathrm{C}\right.$ of $\left.\mathrm{C}_{60}, \mathrm{C}_{60}-\mathrm{C}\right), 68.28\left(1 \mathrm{C}, \mathrm{OCH}\left(\mathrm{CH}_{3}\right)_{2}\right), 22.31$ (1C, $\left.\mathrm{OCCH}_{3}\right), 15.67\left(2 \mathrm{C}, \mathrm{CH}\left(\mathrm{CH}_{3}\right)_{2}\right)$. UV-vis (in toluene) $\lambda_{\text {max }}: 320$, $429 \mathrm{~nm}$.

\section{Preparation and spectral characterization of $2 \mathrm{e}$}

The procedure was similar to that used for the preparation of 2a, except that 1e (62 equiv., $3.10 \mathrm{mmol}, 500 \mu \mathrm{L}$ ) was used instead of 1a, and a temperature of $50{ }^{\circ} \mathrm{C}$ was used. The reaction afforded $2 \mathrm{e}\left(16.6 \mathrm{mg}, 57 \%\right.$ based on the consumed $\mathrm{C}_{60}$ ) as an amorphous brown solid along with the recovered $\mathrm{C}_{60}(11.9 \mathrm{mg}$, $33 \%$ ). MALDI-TOF MS $m / z$ calcd for $\mathrm{C}_{68} \mathrm{H}_{12} \mathrm{O}_{3}{ }^{+}[\mathrm{M}]^{+}$876.0781, found 876.0743. ${ }^{1} \mathrm{H}$ NMR (600 $\left.\mathrm{MHz}, \mathrm{CDCl}_{3}\right) \delta 2.85(\mathrm{~s}, 3 \mathrm{H}), 1.73$ (s, 9H). $\left.{ }^{13} \mathrm{C} \mathrm{NMR} \mathrm{(151} \mathrm{MHz,} \mathrm{CDCl}_{3}\right) \delta 191.82\left(1 \mathrm{C}, \mathrm{COCH}_{3}\right)$, 162.17 (1C, $\left.\mathrm{CO}_{2} \mathrm{C}\left(\mathrm{CH}_{3}\right)_{3}\right), 145.55$ (2C), 145.18 (2C), 145.08 (4C), 145.01 (6C), 144.97 (3C), 144.62 (4C), 144.56 (4C), 144.41 (4C), 143.71 (3C), 143.03 (1C), 142.99 (1C), 142.89 (6C), 142.86 (3C), 142.12 (3C), 141.74 (2C), 141.69 (2C), 140.90 (2C), 140.85 (2C), 139.17 (2C), 137.90 (2C), $84.87\left(1 \mathrm{C}, \mathrm{CO}_{2} C\left(\mathrm{CH}_{3}\right)_{3}\right), 72.59\left(2 \mathrm{C}, \mathrm{sp}^{3}-\right.$ $C$ of $\left.\mathrm{C}_{60}\right), 60.32\left(1 \mathrm{C}, \mathrm{CCOCH}_{3}\right), 28.14\left(1 \mathrm{C}, \mathrm{COCH}_{3}\right), 27.92(3 \mathrm{C}$, $\left.\mathrm{C}\left(\mathrm{CH}_{3}\right)_{3}\right)$. UV-vis (in toluene) $\lambda_{\text {max }}: 330,429 \mathrm{~nm}$.

\section{Preparation and spectral characterization of $3 \mathrm{e}$}

The procedure was similar to that used for the preparation of 3a, except that 1e (62 equiv., $3.10 \mathrm{mmol}, 500 \mu \mathrm{L}$ ) was used instead of 1a. The reaction afforded 3 e $(14.0 \mathrm{mg}, 66 \%$ based on the consumed $\mathrm{C}_{60}$ ) as an amorphous brown solid along with the recovered $\mathrm{C}_{60}(18.7 \mathrm{mg}, 52 \%)$. MALDI-TOF MS $\mathrm{m} / \mathrm{z}$ calcd for $\mathrm{C}_{68} \mathrm{H}_{12} \mathrm{O}_{3}{ }^{+}[\mathrm{M}]^{+}$876.0781, found 876.0753. ${ }^{1} \mathrm{H}$ NMR $(600 \mathrm{MHz}$, $\left.\mathrm{CDCl}_{3}\right) \delta 2.81(\mathrm{~s}, 3 \mathrm{H}), 1.52(\mathrm{~s}, 9 \mathrm{H}) .{ }^{13} \mathrm{C} \mathrm{NMR}\left(151 \mathrm{MHz}, \mathrm{CDCl}_{3}\right)$ $\delta 168.33\left(1 \mathrm{C}, \mathrm{OCCH}_{3}\right), 163.25$ (1C, $\left.C=\mathrm{O}\right), 148.53(2 \mathrm{C}), 147.92$ (1C), 147.48 (2C), 147.20 (1C), 146.35 (2C), 146.10 (2C), 146.06 (2C), 145.90 (2C), 145.85 (2C), 145.60 (2C), 145.28 (2C), 145.07 (2C), 144.90 (2C), 144.71 (2C), 144.52 (2C), 144.44 (2C), 144.16 (2C), 142.73 (2C), 142.68 (2C), 142.60 (2C), 142.50 (2C), 142.35 (2C), 142.21 (4C), 141.45 (2C), 141.38 (2C), 139.79 (2C), 139.17 (2C), 137.32 (2C), 135.19 (2C), 105.67 (1C, $C \mathrm{C}=\mathrm{O}), 81.18$ (1C, $\left.\mathrm{CO}_{2} \mathrm{C}\left(\mathrm{CH}_{3}\right)_{3}\right), 28.35\left(3 \mathrm{C}, \mathrm{C}\left(\mathrm{CH}_{3}\right)_{3}\right), 15.55\left(1 \mathrm{C}, \mathrm{CH}_{3}\right),\left(\mathrm{sp}^{3}-\mathrm{C}\right.$ of $\mathrm{C}_{60}$ not found). UV-vis (in toluene) $\lambda_{\max }: 320,430 \mathrm{~nm}$.

\section{Preparation and spectral characterization of $2 f$}

The procedure was similar to that used for the preparation of 2a, except that 1 f (78 equiv., $3.90 \mathrm{mmol}, 500 \mu \mathrm{L}$ ) was used instead of $1 \mathrm{a}$, and a temperature of $50{ }^{\circ} \mathrm{C}$ was used. The reaction afforded $2 \mathrm{f}$ ( $19.1 \mathrm{mg}, 56 \%$ based on the consumed $\mathrm{C}_{60}$ ) as an amorphous brown solid along with the recovered $\mathrm{C}_{60}(7.2 \mathrm{mg}$, $20 \%$ ). MALDI-TOF MS $m / z$ calcd for $\mathrm{C}_{66} \mathrm{H}_{8} \mathrm{O}_{3}{ }^{+}[\mathrm{M}]^{+}$848.0468, found 848.0437. ${ }^{1} \mathrm{H} \mathrm{NMR}\left(600 \mathrm{MHz}, \mathrm{CDCl}_{3}\right) \delta 4.11(\mathrm{~s}, 3 \mathrm{H}), 3.26$ $(\mathrm{q}, J=7.2 \mathrm{~Hz}, 2 \mathrm{H}), 1.39(\mathrm{t}, J=7.2 \mathrm{~Hz}, 3 \mathrm{H}) .{ }^{13} \mathrm{C} \mathrm{NMR}(151 \mathrm{MHz}$, $\left.\mathrm{CDCl}_{3}\right) \delta 195.93\left(1 \mathrm{C}, \mathrm{COCH}_{2} \mathrm{CH}_{3}\right), 164.22\left(1 \mathrm{C}, \mathrm{CO}_{2} \mathrm{CH}_{3}\right), 145.62$ (2C), 145.31 (4C), 145.29 (4C), 145.24 (4C), 145.11 (2C), 144.99 (2C), 144.88 (2C), 144.76 (4C), 144.65 (4C), 143.92 (2C), 143.90 (2C), 143.22 (1C), 143.17 (1C), 143.09 (6C), 143.04 (2C), 142.29 (4C), 141.95 (2C), 141.91 (2C), 141.11 (2C), 141.07 (2C), 139.34 (2C), 138.16 (2C), $72.31\left(2 \mathrm{C}, \mathrm{sp}^{3}-\mathrm{C}\right.$ of $\left.\mathrm{C}_{60}\right), 58.96\left(1 \mathrm{C}, \mathrm{CCOCH}_{2}\right.$ $\mathrm{CH}_{3}$ ), 53.79 (1C, $\mathrm{OCH}_{3}$ ), 34.77 (1C, $\mathrm{CH}_{2} \mathrm{CH}_{3}$ ), $8.54\left(1 \mathrm{C}, \mathrm{CH}_{2} \mathrm{CH}_{3}\right.$ ). UV-vis (in toluene) $\lambda_{\max }: 330,429 \mathrm{~nm}$.

\section{Preparation and spectral characterization of $3 f$}

The procedure was similar to that used for the preparation of $3 \mathbf{a}$, except that 1 f (78 equiv., $3.90 \mathrm{mmol}, 500 \mu \mathrm{L}$ ) was used instead of 1a. The reaction afforded $3 \mathrm{f}(11.4 \mathrm{mg}, 61 \%$ based on the consumed $\mathrm{C}_{60}$ ) as an amorphous brown solid along with the recovered $\mathrm{C}_{60}$ (20.2 mg, 56\%). MALDI-TOF MS $m / z$ calcd for $\mathrm{C}_{66} \mathrm{H}_{8} \mathrm{O}_{3}{ }^{+}[\mathrm{M}]^{+}$ 848.0468, found 848.0425. ${ }^{1} \mathrm{H}$ NMR $\left(600 \mathrm{MHz}, \mathrm{CDCl}_{3}\right) \delta 3.87(\mathrm{~s}$, $3 \mathrm{H}), 3.34$ (q, $J=7.8 \mathrm{~Hz}, 2 \mathrm{H}), 1.64(\mathrm{t}, J=7.2 \mathrm{~Hz}, 3 \mathrm{H}) .{ }^{13} \mathrm{C}$ NMR $(151$ $\left.\mathrm{MHz}, \mathrm{CDCl}_{3}\right) \delta 173.88\left(1 \mathrm{C}, \mathrm{OCCH}_{2} \mathrm{CH}_{3}\right), 164.52(1 \mathrm{C}, C=\mathrm{O}), 148.68$ (2C), 148.15 (1C), 147.42 (1C), 147.31 (2C), 146.56 (2C), 146.34 (2C), 146.26 (2C), 146.14 (2C), 146.07 (2C), 145.77 (2C), 145.50 (2C), 145.29 (2C), 145.14 (2C), 144.90 (2C), 144.64 (2C), 144.50 (2C), 144.34 (2C), 142.92 (2C), 142.89 (2C), 142.81 (2C), 142.66 (2C), 142.57 (2C), 142.45 (2C), 142.40 (2C), 141.71 (2C), 141.58 (2C), 140.01 (2C), 139.64 (2C), 137.59 (2C), 135.39 (2C), 104.26 (1C, $C \mathrm{C}=$ O), 102.87 (1C, sp ${ }^{3}-\mathrm{C}$ of $\left.\mathrm{C}_{60}, \mathrm{C}_{60}-\mathrm{O}\right), 72.31\left(1 \mathrm{C}, \mathrm{sp}^{3}-\mathrm{C}\right.$ of $\mathrm{C}_{60}, \mathrm{C}_{60}-\mathrm{C}$ ), $51.26\left(1 \mathrm{C}, \mathrm{OCH}_{3}\right), 30.17$ (1C, $\left.\mathrm{CH}_{2} \mathrm{CH}_{3}\right), 11.83\left(1 \mathrm{C}, \mathrm{CH}_{2} \mathrm{CH}_{3}\right)$. UV-vis (in toluene) $\lambda_{\text {max }}: 320,429 \mathrm{~nm}$.

\section{Conflicts of interest}

There are no conflicts of interest to declare. 


\section{Acknowledgements}

This work was supported by the National Natural Science Foundation of China (21602192) and Shandong Provincial Government-Sponsored Study Abroad Program "Provincial School Joint Training Plan” (2019).

\section{Notes and references}

1 H. W. Kroto, J. R. Heath, S. O. Obrien, R. F. Curl and R. E. Smalley, Nature, 1985, 318, 162.

2 H. W. Kroto, Pure Appl. Chem., 1990, 62, 407.

3 H. W. Kroto, A. W. Allaf and S. P. Balm, Chem. Rev., 1991, 91, 1213.

4 W. Krätschmer, L. D. Lamb, K. Fostiropoulos and D. R. Huffman, Nature, 1990, 347, 354.

5 R. Taylor and D. R. Walton, Nature, 1993, 363, 685.

6 Y. Matsuo and E. Nakamura, Chem. Rev., 2008, 108, 3016.
7 H.-S. Lin and Y. Matsuo, Chem. Commun., 2018, 54, 11244. 8 E. Nakamura and H. Isobe, Acc. Chem. Res., 2003, 36, 807.

9 M. D. Tzirakis and M. Orfanopoulos, Chem. Rev., 2013, 113, 5262.

10 C. Tian, M. Chen, H. Tian, Z. Nan, Y. Liang and Z. Wei, J. Mater. Chem. C, 2019, 7, 12688.

11 D. Iohara, F. Hirayama, M. Anraku and K. Uekama, ACS Appl. Nano Mater., 2019, 2, 716.

12 C. Bingel, Chem. Ber., 1993, 126, 1957.

13 X. Camps and A. Hirsch, J. Chem. Soc., Perkin Trans. 1, 1997, (11), 1595.

14 C. Li, D. Zhang, X. Zhang, S. Wu and X. Gao, Org. Biomol. Chem., 2004, 2, 3464.

15 G.-W. Wang and F.-B. Li, Org. Biomol. Chem., 2005, 3, 794. 16 T.-H. Zhang, G.-W. Wang, P. Lu, Y.-J. Li, R.-F. Peng, Y.-C. Liu, Y. Murata and K. Komatsu, Org. Biomol. Chem., 2004, 2, 1698. 17 S. Chen, Z.-J. Li and X. Gao, J. Org. Chem., 2016, 81, 121. 